\title{
The State of Research on Islamic Spain
}

The era of Muslim rule in Spain (711-1491 CE) witnessed great contributions in many areas of knowledge and learning. Rapid strides were made in such diverse fields as art and architecture, agriculture and handicrafts, linguistics and literature, humanities and social studies, music and poetry, and the physical and mechanical sciences. In fact, Islamic Spain, known to the Muslim world as al Andalus, served as a bridge for the transfer of the knowledge and wisdom of Classical Greece to Europe, a process that eventually led to the European Renaissance.

The achievements of al Andalus will not be discussed in this paper. Rather, a survey of current reasearch activities focusing on al Andalus will be presented. The areas covered are Europe, North America, North Africa, and parts of Asia. Latin American activities have not been surveyed due to the nonavailability of sources.

\section{Europe}

Europe has been the center of research on al Andalus. Various periodicals have served as major sources of information: Al-Andalus (Madrid 1933), Hesperis (Paris 1921-59), Hesperis-Tamuda (Rabat 1960), Miscellancea de Estudios Arabes y Hebraicos (Granada 1952), Revista de Instituto Egypcio de Studios Islamicos (Madrid 1953), Revue de la Occident Musulman et la Mediterranee (Aix-en-Provence 1966), Boletin de la Association Espaniola de Orientalistas (Madrid 1965), and Cuadernos de la Alhambra (Granada 1965).

Certain important books have also appeared, such as Peres: la Poisie Andalousie, which includes a history of that period. Introductions to editions of texts and translations relate important information about al Andalus under the al Murābitūn and the al Mu'ahhidūn dynasties. Hourani (1961) has written an excellent book: Averroes: On the Harmony of Religion and Philosophy. Memorial volumes in honor of E. Levi-Provençal, G. and W. Marcais, Menendes Pidal, Millas Vallicrosa y Parya, A. H. and R. Basset, H. A. R. Gibb and H. Wehr also contain much valuable data.

Mention must be made of translations by institutes devoted to the study of al Andalus: Dār al Thaqāfah (Beirut) has published valuable books, as have several Spanish and North African organizations (i.e., Conjeyo Superior de Investigaciones Cientificas [Madrid], Instituto de Studios Islamicos [Madrid], Institute des Haut-Etudes Marocaines [Paris- 
Rabat], University of Muhammad V [Rabat], Instituto General Franco de Estudios y Investigacion Hispano-Arab [Tetuan, Morocco], and the University of Algiers [Algiers] and the University of Tunis [Tunis]). The Instituto Culturale Hispano-Arab, under Madrid's Ministry of External Affairs, is also doing useful studies.

In Spain itself, there are approximately four hundred scholars working on al Andalus. Nearly all Spanish universities have Arabic and Islamic studies departments. The University of Alicante even has a separate institute devoted to studying such fields as art, history, literature, medicine, philosophy, and the sciences. A member of its staff, Mikel Epalza, is the deputy director and editor of Sharq-al-Andalus Estudios Arabes.

Such studies are also being carried out by Hispano-Arab Cultural Institute under the Spanish Ministry of External Affairs. On the occasion of "The Meeting of the Two Worlds: Europe and Americas," this institute prepared over three dozen studies under the project "Andalus II 1992: The Rediscovery of Arab Spain" in cooperation with Egypt, Mauritania, Morocco, Algeria, and Tunisia. Spain has established joint commissions with each of these countries. Several exhibitions, seminars, and workshops were held during the last three years, preparatory to the 1992 celebrations. At the World's Fair, hosted by Seville (21 April - 12 October 1992), the Arab League pavilion was surrounded by member states and featured seminars and exhibitions, with audiovisual projections, on their history, culture, and contribution to the study of al Andalus.

The Egyptian Institute, established in Madrid during 1953, has carried out many studies on al Andalus. The Instituto Occidental de Cultura Islamica, also based in Madrid, held a seminar during September 1988 at Teruel, where, along with presentation of papers, different Andalusian dishes were served for lunch and dinner.

Various estimates have been given for the number of manucripts that remained uncatalogued in Escorial and other cities. The one most widely accepted is two thousand five hundred. It is essential that students pursuing doctoral work in Spanish and Medieval Studies should be awarded fellowships in order to further our knowledge of al Andalus. For this purpose, knowledge of Arabic and Spanish is required. The Spanish government grants such fellowships, lasting for one to nine months, every year.

Although detailed data on relevant research in other European countries is lacking, we know that there are thousands of useful manuscripts located in London, Paris, Berlin, Rome, and Vienna. Some noted European scholars in this area are: H. J. Kriss, H. Tensach, W. Hoinnerbach, W. Dressendorfer, R. Konke, and P. Alcala (all from Germany); R. Arie, A. Bel, E. Levi-Provençal, H. Terrace, G. Marcais (all from France); R. W. J. Austin, A. J. Arberry, S. M. Stern, D. Hill, and Y. Zaki (all from 
England); R. Dozy, R. Scheindlin, and R. P. Shiaparelli (all from Holland); W. von Hoenulach (Switzerland); and C. Shiaparelli (Italy).

\section{North America}

After the Second World War, the United States became a major center of research on al Andalus. Many university departments dealing with medieval, Spanish, and historical studies are actively engaged in studying al Andalus. Cornell University offers a course on "Islamic Spain: Society and Culture," the first of its kind in the United States. At New York University's School of Architecture, there is a course on Islamic architecture, which includes a segment on Muslim Spain. O. Grabar, who occupied the Massachusetts Institute of Technology's Chair of the Agha Khan School of Islamic Architecture, has published several monographs on this subject. He has also edited a book on Islamic architecture with articles from such well-known scholars as England's Y. Zaki. I. Kostov of the University of California at Berkeley has published History of World Architecture, which contains a chapter on Islamic architecture in Spain and other countries. The University of California at Los Angeles has gone to the extent of setting up an Institute of Medieval Mediterranean Studies.

A distinguished and prolific writer on Muslim Spain is C. Butterworth, who has authored eleven books on Averroes, apart from many articles on various Islamic disciplines. Other scholars are T. Glick, who has written Cultural History of Christians and Muslims in Spain; G. Attiyeh, who has translated Ibn Tufayl; S. H. Nasr of George Washington University, who has worked on Andalusian Sufis and is now preparing a film ("Islam and the West"), a major part of which will be devoted to al Andalus; T. B. Irving has written extensively on al Andalus (i.e., Falcon of Spain, about 'Abd al Rahmān al Dakhīl); and E. Kaubach of the Univversity of Texas (Austin), who has written on a hitherto unknown topic: "Naturally Prophetic Powers of Imagination according to Avicenna."

Among other scholars doing research on al Andalus are: P. Chevedden (Salem State University), N. Roth (University of Wisconsin), J. Boswell (Yale University), A. J. Cardenas (University of New Mexico), R. A. Macdonald (University of Richmond), J. R. Craddock and J. T. Monroe (University of California at Berkeley), D. E. Carpenter (Boston University), D. F. Ruggles (University of Pennsylvania), G. Kubler (Yale University), G. Collins (Columbia University), D. Gephard (University of California at Santa Barbara), J. Henry and M. Yardley (University of Texas at Arlington) C. H. Krinsky (New York University), A. A. Newman, J. F. Callaghan, and M. Fletcher. 
Two Canadian scholars are known to be interested in Islamic Spain: O. Hegyi (University of Toronto, Mississigua) teaches a course on Golden Age Spanish and writes on al Jamiado, and A. Kassis (University of British Columbia) conducted a conference on Islamic Spain two years ago.

\section{Africa}

The countries of North Africa, especially Morocco (the gateway to Spain), are said to have several thousand manuscripts. Although no separate institute has been established, all universities have scholars who are conducting research on al Andalus. Among these people are U. Zajjah, H. Farhat, and A. Kettani. The King 'Abd al 'Azīz Foundation held a colloquium on western Islamic manuscripts at Casablanca, Morocco, during April 1988. This event was attended by scholars from various European and Arab countries. Periodic seminars have been conducted in the Moroccan cities of Tuja and Tetuan. In 1992, the Moroccan Academy of Letters held its meeting in Andalusia.

In Tunisia, there are an estimated forty thousand manuscripts. In addition, there is a private institute for these studies at Zaghuan. A. Tamimi, a well-known Tunisian scholar, is very active in this field. In Egypt, several scholars have served as directors of the Egyptian Institute at Madrid and have written on al Andalus, such as A. Heba, M. al Makki, and A. B. Nuwaire. A. Djaber of Algeria is also doing a great deal of research.

\section{The Indian Subcontinent}

In pre-partition India (i.e., contemporary India, Pakistan, and Bangladesh), considerable work had been done by scholars on al Andalus. Such studies started at the very beginning of British colonial rule. Among these scholars are: Sir Syed Ahmad Khan (translated Marca of Calict's History of Spain), H. A. Siddiqi of Saharanpur (translated Lane-Poole's Moors of Spain), Syed A. G. Warsi (revised translation of Lane-Poole's Moors of Spain), Syed Ameer Ali (History of the Saracens), Hafiz Ahmad Ali Khan Shauq (translated Ibn Jubayr), S. Hasan (translated Yusuf Antonio), A. H. Sharar (revised Yusuf Antonio Ronde), H. Rahman (translated Nafh al Tiwāl), S. P. Scot (History of the Moorish Empire in Europe as Akhbār ul Andalus), H. Lee (The Moriscoes of Spain as al Muwallidin), N. Rehman (translated 'Abd al Wahīd of Morocco's al Mu'jab fi Talkhis Akhbār al Muwahidīn as Khilafat Mohadin); J. Rehman (translated Ibn Qutīyah's Iftitāh al Andalus), and M. Inayatullah (Historic Geography of Andalus). He also translated by R. Dozy's Span- 
ish Islam: A History of Muslims in Spain, as Ibrat Nama Andalus.

Other scholars who wrote on Andalusian history include A. S. K. Najibabadi (Muslims of Andalus); M. Khan, Maikash, U. A. Mirza (Muslims of Andalus); Syed Riasat A. Nadwi (published the first volume of Rijāl Andalus); muftis Z. Abidin and I. Shehabi (compilers of Tärikh Millat, the fourth volume of which deals with al Andalus). Maulana A. H. Sharar of Lucknow wrote a number of Urdu novels describing the conquest of Spain and the social life of its people (Fath Andalus and Flora Florinda). Most recently, M. S. Khan of the Indian Academy of Sciences (Calcutta) is working on Ibn Sa'd's Tabaqāt al Umam.

Among the institutions that published works on al Andalus are: Darul-Musannifin of Azamgarh (translations of Tabaqāt al Umam and Yahya of Seville's Kitāa al Falāhāt); Nadvat-ul-Musannifin of Delhi (translation of Ibn 'Abd al Barr's Jämi' Bayān al 'llm, and the accounts written by Qazi Wali Muhammad and Iqbal on their respective visits to Spain); and Dar-ul-Tarjuma of Hyderabad (translated al Ihätah fï Akhbār al Ghranāțah, Ibn Athīr, Ibn Khaldūn, Ibn Hazm's Kitāb al Fisal fì Milal wa Nihal, and Ibn 'Arabīs Fusūs al Hakam). The Nafis Academy of Karachi also published a translation of al lhātah fi Akhbār Gharnātah, Tarikh Ibne Khaldoon and various travelogues. In addition, it reprinted books published earlier by Darul Tarjuma and Jamia Usmania, both of which are in Hyderabad, Deccan.

After partition, Pakistani and Bangladeshi scholars maintained an active interest in al Andalus. Islamic history was taught at the bachelor's and master's levels in universities, and the topic of Islamic Spain was allowed as a paper. This program was continued in Karachi University even after other universities began to teach Islamic history as part of general history. As an aside, one of the recommendations of the Mu'tamar al ‘Ālam al Islāmī's International Seminar on Muslim Heritage in Spain, which was held from 14-17 November 1991 in Lahore, was to restore Islamic history as a separate discipline with Islamic Spain as a paper.

Textbooks on al Andalus have been written, one example being R. A. Nadvi's Musalmans in Andalus. He has also written a novel (Aamir-binAbdullah) dealing with this issue, as has N. Hijazi (Shaheen and Yusuf bin Tashfin, which have been televised). Other scholarly works include: I. Shehabi (Salātīn Andalus); A. Q. Zia (Tārikh Andalus); Z. U. Zubairi (Omayyad History of Andalus); S. M. Imamuddin (Muslim Spain: A Political History, Economic History of Spain, and other books); I. H. Burney (Muslim Spain: A Political and Cultural History); N. A. Nasir (Tārikh Spain); M. S. H. Masumi (Kitāb al Nafs of Ibn Bäjjah. His Kitāb al Kawn wa al Fașād, Kitāb al Hayawān, Risālah al Bāhirah, and Ibn Hazm al-Zahiri are also noteworthy); T. Hashmi (Muslim Spain's Contri- 
bution to Science); and A. N. M. Raisuddin, a Bangladeshi who did his doctorate on the contributions of Muslim Spain to hadith.

Spurred by the five-hundredth anniversary of the "discovery" of the Americas by Columbus, redesignated as a "Meeting of Two Worlds: Europe and the Americas," the World Muslim Congress of Karachi organized an international seminar. This was held in Lahore during 14-17 November 1991 in cooperation with both the federal and the Punjab provincial governments. At this seminar, more than sixty papers dealing with the intellectual and other contributions made by the scholars and people of al Andalus were presented. In conjunction with this seminar, there was an exhibition of books and photographs dealing with al Andalus. The seminar was inaugurated by Prime Minister Sharif and the closing session was chaired by the chairman of the Senate. In addition, there was a Youth Essay Contest and many television and radio programs as well as media articles were developed for publicity purposes.

The seminar closed with the proclamation of the Lahore Declaration. This document envisaged the establishment of Centers of Excellence on Islamic Heritage, the acceleration of efforts to remove from Western textbooks all material that is either distorted or hostile to Islam, the founding of chairs in Hispano-lslamic studies in universities located in the West, the continued support of the Islamic Thought Project of the World Muslim Congress, the promotion of essay contests, radio and TV programs, seminars, exhibitions and so on.

It is hoped that all of these will be carried out under the auspices of the Organization of the Islamic Conference, both at its headquarters and at its offices in member countries. In addition, the formation of a cell in COMSTECH (Islamabad) for the study of the contributions of al Andalus to the scientific knowledge was also proposed.

\section{Selected References}

Castro, Amerigo. The Structure of Spanish History. Princeton: Princeton University Press, 1922.

Chejne, Anwar. Muslim Spain: Its History and Culture. Minneapolis: Minnesota University Press, 1974.

Immamuddin, S. M. A Political History of Muslim Spain. Dacca: Najmeh Sons, 1969.

Irving, T. B. Falcon of Spain. Lahore: Sh. M. Ashraf, 1962.

Nasr, S. H. Science and Contribution in Islam. Lahore: Sohail Academy, 1987. 
Masumi, M. S. H. "The Earliest Invasion of Spain." Islamic Studies (April 1964).

Personal correspondence with scholars in the United States, Canada, England, Spain, France, Germany, and Morocco.

Raisuddin, A. N. M. "Muslim Arrival in Spain and Their Contribution to Human Civilization." Paper presented at a seminar at Lahore, Pakistan, 14-17 November 1991.

S. A.H. Ahsani

Adjunct Professor, University of Texas at Arlington

Arlington, Texas

Chief Coordinator, World Muslim Congress

International Commission on Muslim Heritage in Spain 